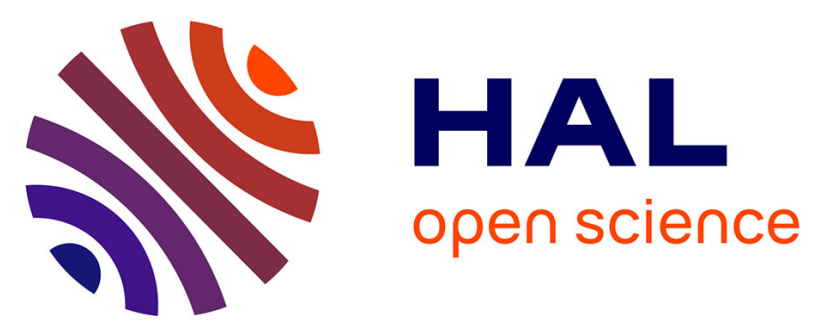

\title{
SYNCHRONIZATION FO A Q-SWITCHED Nd-YAG PUMPED DYE LASER AND AN EXCIMER LASER FOR TIME-RESOLVED RAMAN EXPERIMENTS
}

C. Allet, G. Buntinx, N. Locoge-Karbowski, O. Poizat

\section{- To cite this version:}

C. Allet, G. Buntinx, N. Locoge-Karbowski, O. Poizat. SYNCHRONIZATION FO A Q-SWITCHED Nd-YAG PUMPED DYE LASER AND AN EXCIMER LASER FOR TIME-RESOLVED RAMAN EXPERIMENTS. Journal de Physique IV Proceedings, 1991, 01 (C7), pp.C7-463-C7-466. 10.1051/jp4:19917123 . jpa-00250773

HAL Id: jpa-00250773 https://hal.science/jpa-00250773

Submitted on 1 Jan 1991

HAL is a multi-disciplinary open access archive for the deposit and dissemination of scientific research documents, whether they are published or not. The documents may come from teaching and research institutions in France or abroad, or from public or private research centers.
L'archive ouverte pluridisciplinaire HAL, est destinée au dépôt et à la diffusion de documents scientifiques de niveau recherche, publiés ou non, émanant des établissements d'enseignement et de recherche français ou étrangers, des laboratoires publics ou privés. 


\title{
SYNCHRONIZATION FO A Q-SWITCHED Nd-YAG PUMPED DYE LASER AND AN EXCIMER LASER FOR TIME-RESOLVED RAMAN EXPERIMENTS
}

\author{
C. ALLET, G. BUNTINX, N. LOCOGE-KARBOWSKI and O. POIZAT* \\ Laboratoire de Spectrochimie Infrarouge et Raman, CNRS UPR A 2631 L USTLFA, Bât. C.5, \\ F-59655 Villeneuve d'Ascq cedex, France \\ *Laboratoire de Spectrochimie Infrarouge et Raman, CNRS UPR A 2631 T, 2 rue Henri Dunant, \\ F-94320 Thiais, France
}

\begin{abstract}
A time resolved resonance Raman experimental set-up is described. It is based on the use of two independent lasers : a Q-switched Nd-YAG pumped dye laser and an excimer laser. A synchronization electronic device has been made to fire the two lasers with variable delays in the range. 0 ns $\rightarrow 10 \mathrm{~ms}$ with a $10 \mathrm{~ns}$ step variation. A drift control unit is used to prevent any slow drifts of the excimer laser. The overall jitter between the two laser pulses is $4.5 \mathrm{~ns}$.
\end{abstract}

\section{INTRODUCTION}

Time resolved resonance Raman spectroscopy is becoming a very powerful technique for the caracterisation of reactive excited states and transient intermediates in fast photochemical reactions $(1,2)$. It provides the means of identifying the transient species, analysing their structures and bonding, and also of monitoring their kinetics of formation and decay. The two-color pump probe method is generally applied. The pump beam is used to start the photochemical reaction by providing energy to the system and promoting the molecules to high excited states. The probe, which is delayed with respect to the pump, is used to excite resonance Raman spectra of the transient species. Both have to be tuned to an electric transition : pump to the absorption wavelength of the molecules in the ground state and probe to the transient absorption of the species being analysed. In recent experiments, we have recorded the resonance Raman spectra of excited states and radicals of various molecules using a Q-switched Nd-YAG pumped dye laser $(3,4,5)$. In these cases, the third or the fourth harmonic of the YAG laser was used as the pump beam and the resonance Raman spectra were excited by the dye laser pumped by either the second or the third harmonic of the YAG. The probe beam was delayed by an optical delay line $(3 \mathrm{~ns} / \mathrm{m})$. Unfortunately, the low quality of the laser beams makes it impossible to use large delays and most experiments were performed in the range 20-50 ns. These experimental conditions did not allow kinetic measurements to be made. In order to overcome this problem, one has to use two independent lasers and synchronize their firing to increase the delays time between the probe and pump beams.

\section{TIME-RESOLVED EXPERIMENTS WITH TWO LASERS}

We have developed a new time-resolved Raman experimental set-up using the same Q-switched Nd-YAG pumped dye laser for the probe beam. An excimer laser was preferred for the pump beam because it is less expensive than a second Nd-YAG pumped dye laser and it emits many wavelengths in the UV region (193, 222, 248, 
$308,351 \mathrm{~nm})$ that are generaliy suitable to fit the absorption spectra of most organic compounds.

We have used an YG 581 C QUANTEL YAG laser pumping a TDL 50 QUANTEL dye laser. The output of the dye laser can be continuously tuned from $220 \mathrm{~nm}$ to 750 nm by direct pumping of "red" dyes or coumarin using the second and the third harmonics of the YAG respectively, or by frequency-doubling and/or frequency mixing. The Excimer laser is a QUESTEK model 2420. The problem was to synchronize the two lasers with as low a jitter as possible. In all cases, the jitter time must be lower than the duration of the laser pulses, i.e. 7-9 ns for the dye and 20-30 ns for the Excimer. The repetition rate was fixed at $10 \mathrm{~Hz}$ because of the YAG laser. The YAG laser needs three trigger orders to be fired; one to command the charge of the capacitors, the second to fire the flashlamps and the third to trig the pockels cell. The capacitors require about $80 \mathrm{~ms}$ to be charged. The excimer laser needs two trigger orders. One to command the charging of the capacitors and the second to fire the thyratron. For this laser, about 30 ms are needed to charge the capacitors. A digital pulse and delay generator has been designed to generate all the trigger orders, all the delays, and also to synchronize a gated multichannel detector with the YAG laser. The schematic diagram and the chronogram of this system are given in figures 1 and 2 .

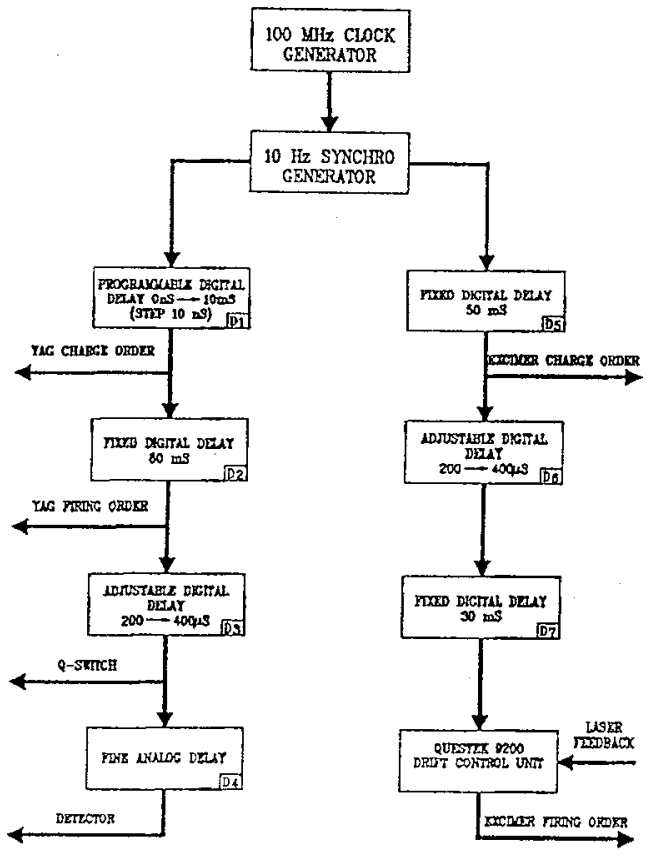

Fig 1: BLOCK DUGRAY OF THE ELECTRONC SYNCHRONTATION MODULF

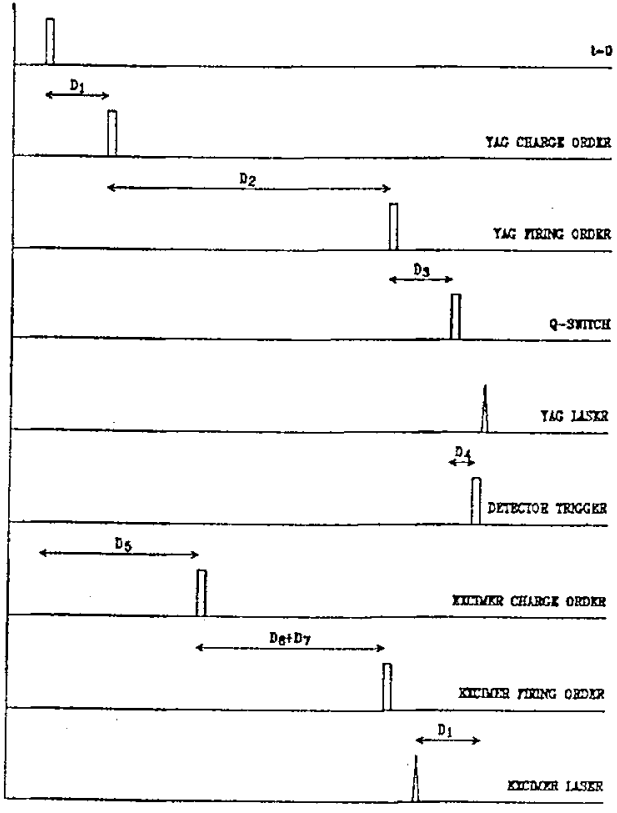

Fig 2: SYNCHRONLATON TULNG 


\section{DESCRIPTION}

The heart of the system is a $100 \mathrm{MHz}$ PLL clock generator that delivers 10 $\mathrm{Hz}, 1 \mathrm{MHz}, 10 \mathrm{MHz}$ and $100 \mathrm{MHz}$ frequencies to the various counters used to generate the delays. A programmable digital delay generator (D1) delays the YAG sequence with respect to the excimer in the range $0 \mathrm{~ns}$ to $10 \mathrm{~ms}$ with a $10 \mathrm{~ns}$ step variation. The charge order is sent to the YAG control unit, and is followed $80 \mathrm{~ms}$ later $\left(D_{2}\right)$ by the firing order. D3 is an adjustable delay that allows the users to trig the Q-switch when the energy is maximum in the YAG rod. Finally, an analog delay (D4) allows the detector to be opened uniquely during the laser pulse. (The response time is much lower in the detector line than in the Q-switched line).

The excimer laser-charge order is sent $50 \mathrm{~ms}$ (Ds) after the YAG laser one in order to prevent any prefiring (6). The delay D6 is used to cancel D3 and also to take into account the difference in the time formation of the YAG and the excimer laser pulses. D7 is the delay time for the capacitors to be charged, then the firing order is sent to the 9200 QUESTEK module. This drift control unit prevents any slow drifts that could appear when changing the operating conditions of the laser, (heating of the thyratron during the first hour of use, change of the laser output power, change in the gas pressure). A feedback control loop using optical fibers measures the delay time $\Delta T$ between the triggering of the module and the actual lasing for each laser pulse. If it varies, the drift control unit automatically modifies the firing order position so as to keep $\Delta \mathrm{T}$ constant. This module allows all drift troubles to be overcame. It adds a $3.5 \mu \mathrm{s}$ delay, that can be compensated by. D6, and has a fine adjustable analog delay that makes it possible to superimpose the YAG and the excimer laser pulses when $D_{1}$ is set to zero. All the electrical triggering signals are then converted into optical signal by LEDs, sent to the lasers by optical fibers and then converted again into electrical signals. It is very important to use this method to overcome the electromagnetic troubles caused by the flashlamps. The total jitter of this experimental set-up has been measured to be $4.5 \mathrm{~ns}$ (about half the duration of the Dye laser pulse).

The rest of the experimental set-up is presented in fig.3. Pump and probe beams are both focused inside a fluorescence cell $\left(10 \times 10 \mathrm{~mm}^{2}\right)$ by the same lens. Raman Iight is collected and imaged onto the entrance silt of a multichannel Raman spectrometer. A triple-stage OMARS 89 DILOR spectrometer is generally used in the visible region and a home-made spectrometer for the 300-420 nm region. This latter is composed of a single-stage $400 \mathrm{~mm}$ Czerny-Turner spectrograph equipped with a UV blazed, ruled grating (1800 grooves per millimeter) and a DILOR UV multichannel intensified photodiode array detector. In order to improve the signal to noise ratio, the detector is gated by applying to the photocathode of the intensifier tube a - 200 Volts pulse during the YAG laser duration. Two electronic devices can be used to generate this pulse. The first one was designed in our laboratory and is based on a coaxial line discharge and avalanche transistors (10 ns FWHM, rise time = fall time $=3 \mathrm{~ns}$ ) while the second one is an AVTECH AVL 3 C model (5 - 100 ns FWHM, rise time $=0.6 \mathrm{~ns}$, fall time $=3 \mathrm{~ns}$ ). The position of the pulse is adjusted by changing the delay D4 (Fig. 1).

This system has been successfully applied to. the studies of the photoreduction of bipyridines by amines (7) and alcohols (8) as well as to the studies of the triplet state of benzil (9). 


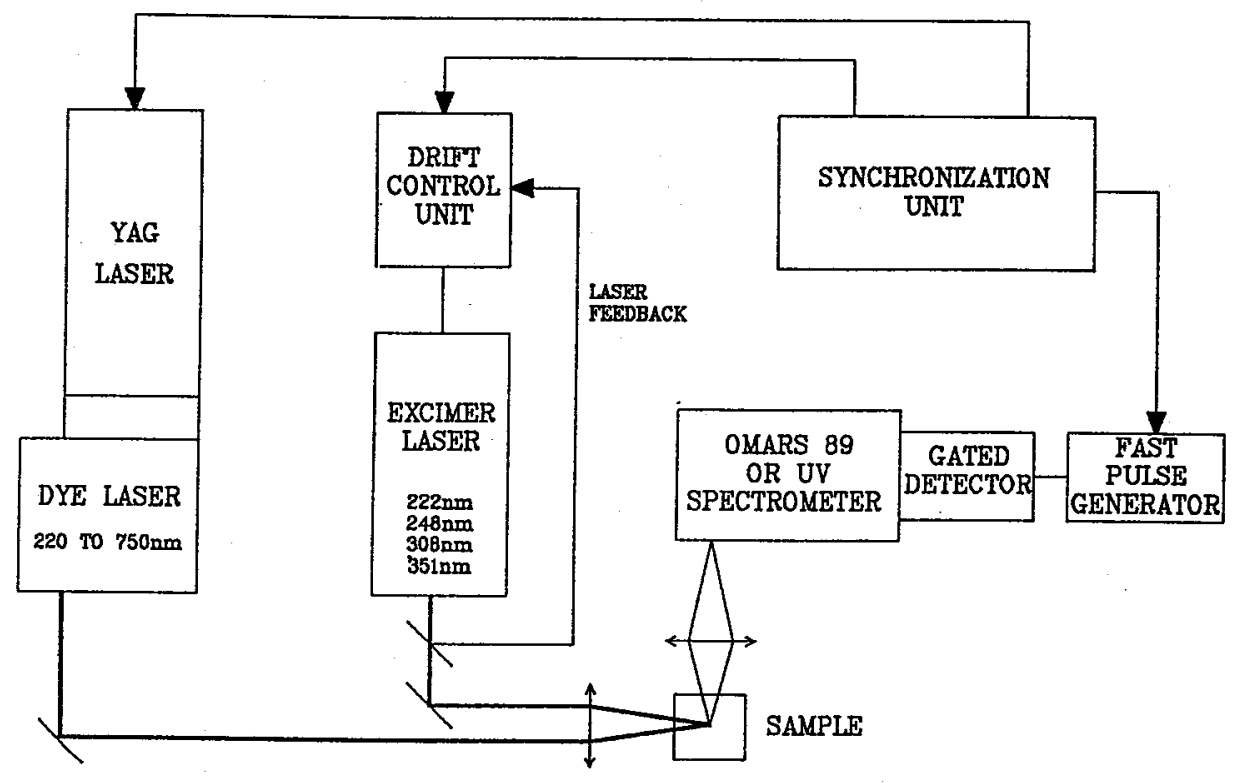

Fig 3: EXPERDMENTAL SET-UP

\section{REFERENCES}

(1) G.H. ATKINSON, Advance in Infrared and Raman Spectroscopy, edited by RJH CLARK and R.E HESTER (Heyden, London, 1982) vol. 9, p.1

(2) Time-resolved vibrational spectroscopy, edited by A. LAUBEREAU and M. STOCKBURGER (Springer-Verlag, Berlin, 1985).

(3) O. POIZAT, A. BOURKBA, G. BUNTINX, A. DEFFONTAINE, M. BRIDOUX, J. Chem. Phys., 1987, 87, 6379.

(4) G. BUNTINX, O. POIZAT, J. Chem. Phys., 1989, 91, 2153.

(5) O. POIZAT, G. BUNTINX, M. VENTURA, M.F. LAUTIE, J. Phys. Chem., 1991, 91, 1245.

(6) QUESTEK Technical manual.

(7) G. BUNTINX, P. VALAT, V. WINTGENS, O. POIZAT, (accepted in J. Phys. Chem).

(8) G. BUNTINX, P. VALAT, V. WINTGENS, O. POIZAT, (in preparation).

(9) N. LOCOGE-KARBOWSKI, G. BUNTINX, O. POIZAT, (in preparation). 